Rev. Int. Contam. Ambie. 35 (Residuos solidos en México) 91-100, 2019

DOI: 10.20937/RICA.2019.35.esp02.09

\title{
EVALUATION OF CONFINEMENT CONDITIONS AND CONTENT OF LIGNOCELLULOSIC COMPOUNDS ON URBAN SOLID WASTE BIODEGRADATION RATES
}

Evaluación de las condiciones de confinamiento y contenido de compuestos lignocelulósicos en la biodegradación de residuos sólidos urbanos en un sitio de disposición final

\author{
María del Consuelo HERNÁNDEZ-BERRIEL ${ }^{1,6}$, Iván Y. HERNÁNDEZ-PANIAGUA ${ }^{2,7}$, \\ Kevin C. CLEMITSHAW ${ }^{3}$, José A. NILA-CUEVAS ${ }^{4}$ and Otoniel BUENROSTRO-DELGADO ${ }^{5,6 *}$
}

${ }^{1}$ División de Estudios de Posgrado e Investigación, Tecnológico Nacional de México, Instituto Tecnológico de Toluca, Av. Tecnológico s/n, Col. Exrancho La Virgen, 52140 Metepec, Estado de México, México

${ }^{2}$ CONACYT, Centro de Investigación en Geografía y Geomática Ing. Jorge L. Tamayo A.C., Contoy 137, Lomas de Padierna, 14240 Ciudad de México, México

${ }^{3}$ Department of Earth Sciences, Royal Holloway University of London, Egham, Surrey, TW20 0EX, UK

${ }^{4}$ Instituto Tecnológico de Lázaro Cárdenas. Tecnológico Nacional de México. Av. Melchor Ocampo No. 2555, cuarto sector, Lázaro Cárdenas, Michoacán. C.P 60950. México

${ }^{5}$ Instituto de Investigaciones en Ciencias de la Tierra, Universidad Michoacana de San Nicolás de Hidalgo, Avenida Francisco J. Mujica S/N, Edificio U-4, Ciudad Universitaria, Morelia Michoacán. C.P. 58030. México

${ }^{6}$ Sociedad Mexicana de Ciencia y Tecnología Aplicada a los Residuos Sólidos, A. C (SOMERS). Av. Cuauhtémoc 403-T6201, Col. Roma Norte, C.P. 06700. Ciudad de México, México

${ }^{7}$ Centro de Ciencias de la Atmósfera, Universidad Nacional Autónoma de México, Circuito de la Investigación Científica s/n, Ciudad Universitaria, 04510 Ciudad de México, México

*Corresponding author; email: otonielb@umich.mx

(Received January 2017; accepted January 2018)

Key words: cellulose, lignin, methane, organic fraction

\begin{abstract}
The organic fraction (OF) is the main component of urban solid wastes (USW) generated in Mexico and other developing countries. The increasing generation of USW in combination with the long periods required for OF stabilization at confinement sites has exceeded the management capacity of environmental authorities. OF biodegradation has commonly been estimated using theoretical approaches and by characterizing fresh USW, while confinement scenarios have been ignored. This study evaluated the effects of composition, biodegradability and confined conditions on biodegradation of USW in a characteristic dumpsite. Biodegradability was evaluated by the characterization of lignocellulosic compounds, biodegradation by volatile solids (VS) and the confinement conditions by temperature, $\mathrm{pH}$ and humidity measurements. On average, the OF represented $56.1 \%$ of the confined USW, and was primarily derived from vegetable wastes $(\sim 78 \%)$. The results indicate heterogeneity in the confined USW composition and different degradation stages. Measurement of temperature, $\mathrm{pH}$, moisture and VS suggests that confinement conditions do not promote the establishment of a microbial consortia that degrades the OF. Lignin (LI) and cellulose + hemicellulose (CE + HE) contents suggest low biodegradability of the USW, which was confirmed by inverse correlations between lignocellulosic content and VS. The common use of soil as cover material in dumpsites allows considerable variations in crucial physical and chemical parameters that, when combined with the high percentages of lignocellulosic compounds in the USW, lead to low biodegradation rates.
\end{abstract}


Palabras clave: celulosa, lignina, metano, fracción orgánica

\section{RESUMEN}

La fracción orgánica (FO) es el componente principal de los residuos sólidos urbanos (RSU) en México y países en desarrollo. La creciente generación de RSU en combinación con tiempos de estabilización prolongados de la FO en los sitios de confinamiento, superan la capacidad de gestión de las autoridades ambientales. La biodegradación de la FO se ha estimado mediante enfoques teóricos y la caracterización de RSU, mientras que el efecto de las condiciones de confinamiento de éstos se omite. Este estudio evaluó los efectos de la composición, la biodegradabilidad y las condiciones de confinamiento sobre la biodegradación de los RSU confinados en un sitio de disposición final. La biodegradabilidad se evaluó mediante la caracterización de compuestos lignocelulósicos, la biodegradación por sólidos volátiles (SV) y las condiciones de confinamiento por la temperatura, $\mathrm{pH}$ y humedad. Los resultados indicaron que la FO representó $56.1 \%$ de los RSU ( $\sim 78 \%$ de residuos vegetales) y diferentes estados de degradación de los RSU. La medición de la temperatura, $\mathrm{pH}$, humedad y $\mathrm{SV}$, sugiere que las condiciones de confinamiento no promueven el desarrollo óptimo de los consorcios microbianos que degradan la FO. Los contenidos de lignina (LI) y de celulosa + hemicelulosa (CE + $\mathrm{HE}$ ) sugieren una baja biodegradabilidad de la FO, la cual se confirmó por correlaciones inversas entre éstos. El uso generalizado del suelo como material de cobertura en los sitios de vertido permite variaciones considerables en los parámetros fisicoquímicos cruciales que, combinados con contenidos altos de compuestos lignocelulósicos en los RSU, conducen a bajas tasas de biodegradación de éstos.

\section{INTRODUCTION}

The integral management of urban solid wastes (USW) is a global problem that affects both developed and developing countries. Unprecedented rates of USW generation have exceeded the operative capacity of collection services and confinement sites worldwide (Srivastava et al. 2014). For example, the amount of USW generated in Mexico increased from $31.5 \mathrm{Mt}$ in 2001 to $42.1 \mathrm{Mt}$ in 2012, corresponding to an annual growth in the generation of $\sim 953.3 \mathrm{kt}$ USW/yr ascribed to the population increase (SEMARNAT 2013). Several developing countries including Mexico have recently introduced stricter environmental regulations with the goal of achieving integral management of USW in the near future. These regulations have included the replacement of open dumps for landfill sites (SEMARNAT 2017). Nevertheless, official reports indicate that a large number of open dumps are still used for USW confinement nationwide. Both currently operating open and closed dumps represent a severe problem for public authorities and private companies in charge of their management, in terms of environmental impact, health and safety (Ezeah et al. 2013).

The application of soil as a cover material on dumpsites is a common practice during the final closure process. However, this has a great influence on the confinement conditions of USW. For example, during the rainy season the soil cover allows rainfall to enter the USW matrix, leading to frequent flooding, whereas high-temperature periods result in increased evaporation rates (Chakraborty et al. 2011, SEMARNAT 2013, Yan et al. 2014). These drastic changes can lead to low biodegradation rates, necessitating long periods for the organic fraction (OF) because of the non-optimal confinement conditions. This will ultimately result in increased post-closure and maintenance costs, as well as extended periods required before returning the land to beneficial use (Wall and Zeiss 1995, Barlaz et al. 2002).

Optimal biodegradation rates in a confined USW site are highly dependent on the availability of electron donors and acceptors, oxygen, temperature, $\mathrm{pH}$, alkalinity, moisture content, and chemical concentrations and their adsorption by particulate matter (Ayse and Ferhan 2003, Angelidaki and Sanders 2004). Among these factors, $\mathrm{pH}$ and moisture content have been reported as the most critical parameters for the establishment of bacterial and fungal consortia that degrade cellulose (CE), hemicellulose (HE) and lignin (LI) contained in the OF (Barlaz 2006, Kelly et al. 2006). Moreover, Reinhart et al. (2002) reported moisture content and nutrient distribution as the key 
factors influencing biodegradation and stabilization of the OF. Similarly, Wall and Zeiss (1995) indicated that moisture content is the principal factor influencing biodegradation rates and consequently, stabilization periods.

The biodegradability of USW is closely related to the level of lignocellulosic compounds (CE, HE and LI) in the fresh OF, which includes food and garden wastes. The OF principal components are carbohydrates and vegetable aromatic polymers with high levels of cellulosic compounds (Barlaz et al. 1989, Alzate-Gaviria et al. 2003, Thompson et al. 2009). During the typical biodegradation process, the hydrolysis of HE by hemicelluloses is more rapid than that of CE by celluloses because of its polymeric aromatic structure, which can even inhibit the hydrolysis process (Crow et al. 2002, Pérez et al. 2002). LI is less inhibitory under aerobic than anaerobic conditions because of its physical association with $\mathrm{CE}$. Moreover, LI is moderately biodegradable under aerobic conditions, but refractory under anaerobic conditions (Komilis and Hamb 2003). Therefore, the fraction of biodegraded CE is highly dependent on the LI content in the USW. The (CE + HE)/LI ratio indicates the degree of lignification in USW, to a certain extent, with ratios $>2$ and $<1$ associated with fresh and biodegraded USW, respectively (Barlaz 2004). Thus, theoretical estimations complemented by experimental tests of biodegradation can be used to provide estimations of stabilization and settlement periods of USW in confinement sites with high confidence (Eleazer et al. 1997, Mehta et al. 2002, Angelidaky and Sanders 2004, Dorairaja and Lifrieri 2010).

The OF biodegradability has been estimated by measuring the LI content, using long-term batch digestion and through respirometric and chemostat studies (Wall and Zeiss 1995, Boni and Musmeci 1998, Raposo et al. 2011). Chandler et al. (1980) observed that biodegradation is linearly related to the LI content under anaerobic conditions, and proposed an empirical equation to estimate the long-term biodegradation (equation 1):

$B=0.83-(0.028) X_{0}$

which considers $B$ as the biodegradable fraction of volatile solids (VS) for $0<B<1$ and $X_{0}$ as the initial content of LI expressed as a percentage of VS. Conversely, the biochemical potential of methane (BMP) has been widely applied to evaluate the anaerobic biodegradability of organic substrates (Kayhanian et al. 1991, Raposo et al. 2011). However,
Raposo et al. (2011) observed a large discrepancy in BMP results that was likely due to variations in protocols among authors and use of different inoculum and substrate.

In Mexico, OF is the main component of USW, accounting for approximately $66 \%$ of the total USW generated in 2012 (SEMARNAT 2013). The OF represents around $50 \%$ of the confined USW, and originates mostly from food and garden wastes (52\%) and paper and cardboard (14\%) (CESOP 2012). Overall, 137 landfills and 24 dumpsites were used for the final disposal of USW in 2009. However, it is very likely that official data only counted regulated sites used to confine USW generated in major urbanities, which would imply that non-regulated sites common in remote areas were not considered. This suggests that a large percentage of USW is confined in sites in which non-optimal conditions prevail, resulting in low biodegradation rates and the need for long periods for OF stabilization. In addition, previous studies estimated biodegradation based only on theoretical calculations and in pilot experiments using fresh USW and synthetic mixes, whereas actual samples of confined USW have not been considered to date. Furthermore, González et al. (2011) found that the biodegradation of confined USW in a dumpsite in Mexico did not coincide with that estimated using the classification-index proposed by Stege and Dávila (2009) or with theoretical calculations based on the confinement time in the site.

Therefore, evaluation of the OF biodegradation stages based on lignocellulosic compound ratios in the confined USW could provide reliable insights into both confinement conditions and biodegradation rates. This study aimed to: $i$ ) determine the biodegradability of confined USW by quantifying lignocellulosic compounds, $i$ ) evaluate the influence of LI content on the biodegradability and stabilization periods of confined USW by performing VS tests, and iii) explain the previously reported differences between the observed biodegradation stages in the confined USW with theoretical calculations.

\section{MATERIALS AND METHODS}

\section{Study site description and USW sampling}

The study site was a closed open dump located $17.1 \mathrm{~km} \mathrm{~W}$ of Morelia, the capital of the state of Michoacán in west central Mexico (Fig. 1). Morelia had a population of 729757 inhabitants in 2010, but this has likely increased to date (INEGI 2010). 


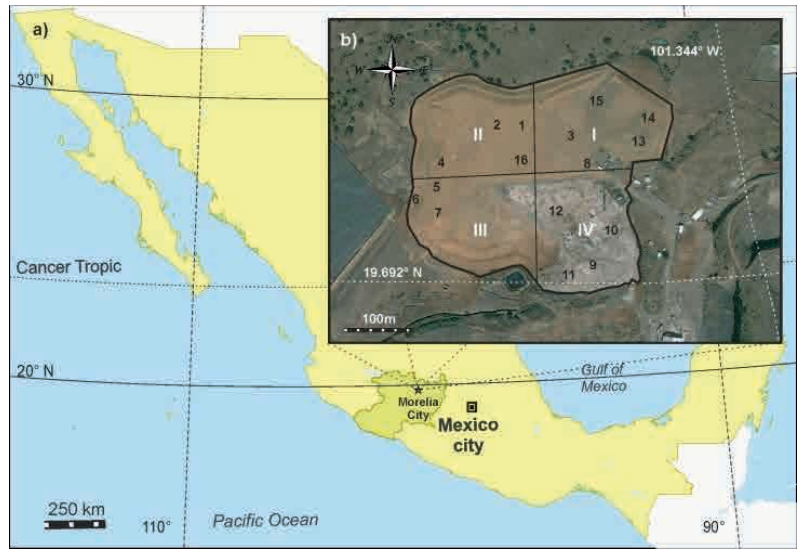

Fig. 1. (a) Location of the study site $17.1 \mathrm{~km}$ west of Morelia in west central Mexico. (b) Distribution of sampling sites within the closed dump. White numbers indicate quadrants (I-IV). Black numbers show the sampling sites
The dumpsite operated from 1983 to 2007 , and confines about 3.85 Mt of USW generated in Morelia (González et al. 2011). To sample the USW, the dump was divided into four quadrants according to USW confinement time (Fig. 1; Table I). Samples of $4 \mathrm{~kg}$ of confined USW were collected from wells at a depth of $3 \mathrm{~m}$ between August and September 2007 during the rainy season. A total of 16 sampling wells, from 3 to 5 per quadrant as shown in figure 1, were established to sample confined USW with different stages of biodegradation. After collection, samples were immediately transferred to labeled polyethylene plastic bags, closed and stored at -4 ${ }^{\circ} \mathrm{C}$. Temperatures at the bottom of each well were measured by placing a digital thermometer (Taylor Precision, model 9878) at $3 \mathrm{~m}$ deep during $20 \mathrm{~s}$ until readings remained steady.

TABLE I. COMPOSITION OF MSW SAMPLES COLLECTED AT THE CLOSED MUNICIPAL DUMP OF MORELIA

\begin{tabular}{|c|c|c|c|c|c|c|c|c|c|c|c|c|c|c|c|c|}
\hline \multirow{2}{*}{$\begin{array}{l}\text { Quadrant } \\
\text { Disposal period } \\
\text { By-product*/well }\end{array}$} & \multicolumn{5}{|c|}{$\begin{array}{c}\text { I } \\
(1983-1988)\end{array}$} & \multicolumn{4}{|c|}{$\begin{array}{c}\text { II } \\
(1989-1994)\end{array}$} & \multicolumn{3}{|c|}{$\begin{array}{c}\text { III } \\
(1995-2001)\end{array}$} & \multicolumn{4}{|c|}{$\begin{array}{c}\text { IV } \\
(2002-2007)\end{array}$} \\
\hline & 3 & 8 & 13 & 14 & 15 & 1 & 2 & 4 & 16 & 5 & 6 & 7 & 9 & 10 & 11 & 12 \\
\hline Non-identifiable material & 31.5 & 32.7 & 67.3 & 19.4 & 21.0 & 55.0 & 35.5 & 11.2 & 37.6 & 70.1 & 71.4 & 43.9 & 44.3 & 36.3 & 74.8 & 50.8 \\
\hline Food waste & 0.0 & 0.0 & 0.9 & 0.6 & 0.1 & 0.0 & 0.1 & 2.5 & 0.0 & 0.0 & 0.0 & 0.0 & 1.3 & 0.0 & 0.0 & 1.2 \\
\hline Garden waste & 3.9 & 0.0 & 1.9 & 3.9 & 2.7 & 1.0 & 3.0 & 1.0 & 0.5 & 7.3 & 0.7 & 1.3 & 0.0 & 0.0 & 0.3 & 5.8 \\
\hline Vegetable fiber & 0.0 & 0.0 & 0.0 & 2.0 & 0.0 & 0.0 & 0.3 & 3.8 & 0.3 & 0.0 & 0.0 & 0.0 & 0.0 & 0.0 & 0.0 & 2.4 \\
\hline Wood & 0.0 & 0.0 & 1.0 & 7.4 & 0.0 & 0.0 & 0.0 & 0.0 & 4.7 & 0.0 & 0.0 & 0.0 & 0.2 & 6.4 & 2.8 & 0.0 \\
\hline Bones & 0.1 & 0.0 & 0.0 & 0.0 & 0.0 & 0.0 & 3.0 & 0.0 & 0.0 & 0.0 & 0.0 & 0.0 & 0.1 & 0.0 & 0.0 & 0.0 \\
\hline Paper & 0.0 & 0.0 & 0.8 & 1.9 & 0.5 & 1.3 & 0.0 & 0.0 & 0.0 & 0.0 & 0.0 & 0.0 & 0.0 & 0.0 & 0.1 & 7.6 \\
\hline Cardboard & 0.5 & 4.4 & 3.9 & 5.8 & 12.6 & 0.0 & 5.8 & 16.9 & 17.2 & 2.4 & 5.3 & 10.4 & 6.8 & 9.4 & 0.0 & 0.0 \\
\hline Tetra Pak & 0.0 & 0.0 & 0.0 & 0.0 & 0.0 & 0.0 & 0.0 & 0.0 & 0.7 & 0.0 & 0.0 & 0.0 & 0.0 & 0.0 & 1.0 & 1.2 \\
\hline Wax paper & 0.0 & 0.0 & 0.0 & 0.0 & 1.4 & 0.0 & 0.4 & 0.0 & 0.0 & 0.0 & 0.0 & 0.0 & 0.0 & 0.0 & 0.0 & 0.0 \\
\hline Cellophane & 0.0 & 0.0 & 0.1 & 0.0 & 0.0 & 0.0 & 0.0 & 0.0 & 0.0 & 0.0 & 0.0 & 0.0 & 0.0 & 2.2 & 0.0 & 0.0 \\
\hline Disposable diapers & 7.9 & 7.6 & 0.0 & 12.7 & 0.0 & 17.1 & 2.2 & 10.6 & 0.0 & 3.1 & 0.0 & 0.0 & 0.0 & 0.0 & 4.7 & 5.0 \\
\hline Ceramics & 0.7 & 0.0 & 0.0 & 1.4 & 0.4 & 0.0 & 0.5 & 1.2 & 0.2 & 0.0 & 1.2 & 5.5 & 0.0 & 0.0 & 0.0 & 1.3 \\
\hline Stones & 10.7 & 0.0 & 13.4 & 8.6 & 49.0 & 9.3 & 28.6 & 2.1 & 8.6 & 4.8 & 8.8 & 11.2 & 14.4 & 9.4 & 6.8 & 3.3 \\
\hline Shoes & 25.4 & 0.0 & 0.0 & 0.0 & 0.0 & 0.0 & 0.7 & 0.0 & 0.0 & 0.0 & 0.0 & 0.0 & 0.0 & 13.5 & 0.0 & 0.0 \\
\hline Hair & 0.0 & 0.0 & 0.0 & 0.0 & 0.1 & 0.0 & 0.4 & 0.0 & 0.0 & 0.0 & 0.0 & 0.0 & 0.0 & 0.0 & 0.0 & 0.0 \\
\hline Rubber & 0.1 & 0.0 & 0.0 & 0.0 & 0.1 & 0.0 & 0.2 & 0.0 & 0.1 & 0.0 & 0.0 & 0.0 & 0.0 & 1.3 & 0.0 & 0.2 \\
\hline Synthetic fiber & 0.0 & 0.0 & 0.4 & 0.0 & 0.0 & 0.0 & 0.1 & 0.0 & 2.7 & 0.0 & 0.0 & 0.0 & 0.0 & 0.0 & 0.0 & 0.1 \\
\hline Snack packaging & 1.1 & 0.0 & 0.3 & 1.1 & 0.7 & 0.4 & 1.4 & 3.0 & 0.7 & 0.0 & 0.0 & 0.0 & 0.0 & 0.0 & 0.0 & 0.7 \\
\hline Plastic film & 1.9 & 20.9 & 3.8 & 23.1 & 3.5 & 7.9 & 8.3 & 20.7 & 6.2 & 4.8 & 0.0 & 16.4 & 4.9 & 9.3 & 4.2 & 8.5 \\
\hline Rigid plastic & 2.4 & 11.8 & 0.4 & 3.0 & 5.1 & 2.9 & 3.8 & 8.4 & 18.7 & 0.9 & 9.9 & 5.9 & 1.4 & 6.6 & 1.0 & 3.3 \\
\hline Polyethylene terephthalate & 0.0 & 0.0 & 0.0 & 0.0 & 0.0 & 0.0 & 0.0 & 0.0 & 0.0 & 0.0 & 0.0 & 0.0 & 3.0 & 0.0 & 1.4 & 5.3 \\
\hline Foam rubber & 0.0 & 0.0 & 0.0 & 0.0 & 1.1 & 0.0 & 0.0 & 0.0 & 0.1 & 0.0 & 0.0 & 0.0 & 0.0 & 0.0 & 0.0 & 0.0 \\
\hline Polystyrene & 0.4 & 1.3 & 0.6 & 0.0 & 0.2 & 0.7 & 1.6 & 0.1 & 0.1 & 0.1 & 0.3 & 0.0 & 3.4 & 0.0 & 0.2 & 0.4 \\
\hline Polypropylene & 0.0 & 0.0 & 0.0 & 0.0 & 0.0 & 0.0 & 0.0 & 0.0 & 0.0 & 0.2 & 0.0 & 0.0 & 0.0 & 0.0 & 0.4 & 0.0 \\
\hline Glass & 5.8 & 2.5 & 1.5 & 8.9 & 1.3 & 2.5 & 2.7 & 3.4 & 0.1 & 0.0 & 1.3 & 4.6 & 9.2 & 5.6 & 0.9 & 2.6 \\
\hline Aluminum & 0.0 & 0.0 & 0.2 & 0.0 & 0.0 & 0.0 & 1.2 & 7.7 & 0.1 & 0.0 & 0.0 & 0.2 & 0.0 & 0.0 & 0.0 & 0.1 \\
\hline Textiles & 6.6 & 0.3 & 0.0 & 0.0 & 0.1 & 1.2 & 0.0 & 0.0 & 1.1 & 6.3 & 1.2 & 0.2 & 10.7 & 0.0 & 1.3 & 0.0 \\
\hline Tin & 0.6 & 0.0 & 3.6 & 0.1 & 0.0 & 0.0 & 0.2 & 7.2 & 0.0 & 0.1 & 0.0 & 0.3 & 0.2 & 0.0 & 0.1 & 0.0 \\
\hline Ferrous material & 0.5 & 18.4 & 0.0 & 0.0 & 0.0 & 0.7 & 0.0 & 0.1 & 0.3 & 0.0 & 0.0 & 0.0 & 0.1 & 0.0 & 0.0 & 0.3 \\
\hline
\end{tabular}

*Expressed in percentage of fresh weight 


\section{Physical and chemical analyses and degradation index}

To perform the physicochemical analyzes, the USW samples were thawed, separated into byproducts and weighed according to the Mexican Official Standard NMX-AA-022-1985 (SEMARNAT 2017). Identified by-products were classified into five categories according to the degradation index proposed in the Mexican Model of Biogas (MMB) (Stege and Dávila 2009).

- Rapidly degraded wastes: food waste, other organics and $20 \%$ of cellulose contained in average diapers.

- Moderately rapidly degraded wastes: plant waste, garden and urban parks waste and toilet paper.

- Moderately slowly degraded wastes: paper, cardboard and textiles.

- Slowly degraded wastes: wood, rubber, leather, bones and straw.

- Non-biodegradable wastes: plastic, glass, metal, concrete and other inert materials.

To evaluate the physical and chemical characteristics of the confined USW, $\mathrm{pH}$, moisture content and VS of each sample were determined in triplicate according to the NMX-AA-25-1984, NMX-AA-016-1984 and 2540G standard methods, respectively (APHA 2005, SEMARNAT 2017). Biodegradation of the OF was calculated as the percentage of VS in the samples of USW.

\section{Determination of lignocellulose content in the organic fraction of USW}

One kilogram of the initially collected and unseparated samples from each well was dried for 3 days at $25{ }^{\circ} \mathrm{C}$ in an oven. Once dry, samples were reduced to a particle diameter $<0.3 \mathrm{~cm}$ in a stainless steel mill (IKAMF 10, Kika Werke). The methodologies of Wise et al. (1946) and Colín-Urrieta et al. (2007) were followed to determine the CE + HE and LI content, respectively, from $20 \mathrm{~g}$ of extractive free dry samples prepared according to the ASTM D1105-56 method (Meltzer 1979).

\section{Mathematical analyses \\ Obtained data were analyzed using descrip- tive statistics. Analysis of variance (ANOVA) and Tukey's HSD (honest significant difference) Pearson correlation coefficients $\left(\mathrm{R}^{2}\right)$ tests were performed us- ing the Statgraphics Plus 5.0 software (Manugistics Inc., Rockville, MD).}

\section{RESULTS AND DISCUSSION}

\section{USW characterization and evaluation of biodeg- radation stages}

Thirty by-products were identified in the samples of confined USW. Table I shows the identified byproducts and estimated percentages by quadrant. A long confinement and degradation period resulted in an average of $43.9 \%$ of USW being classified as non-identifiable. On average, the OF content was $56.1 \%$, which is slightly lower than the value of $63.3 \%$ reported by SEMARNAT (2013) for fresh USW in Mexico in 2012. This difference is due to the biodegradation of OF during the confinement period at the site. Interestingly, recycling carried out during USW transportation from dwellings to the confinement site led to low recovery percentages of highly recyclable materials such as Tetra Pak $(0.2$ $\%)$, aluminum (0.6\%), PET (0.6\%), paper $(0.8 \%)$, tin $(0.8 \%)$, ferrous material $(1.3 \%)$, glass $(3.3 \%)$ and cardboard $(6.3 \%)$. High lignocellulosic content by-products accounted for around $17.2 \%$ of the confined USW, which according to previous reports are cardboard $(6.3 \%)$, hard plant fiber $(0.6 \%)$, wood $(1.4 \%)$, paper $(0.8 \%)$, diapers $(4.4 \%)$, food waste $(0.4 \%)$, garden waste $(2.1 \%)$ and textiles $(1.8 \%)$ (Eleazer et al. 1997).

Categorization of the confined USW samples according to the degradation index proposed in the MMB showed that $45.2 \pm 2.7 \%$ corresponded to rapidly degraded wastes, $2.8 \pm 0.3 \%$ to moderately rapidly degraded wastes, $12.3 \pm 3.0 \%$ to moderately slowly degraded wastes, $1.7 \pm 1.2 \%$ to slowly degraded wastes, and $38.0 \pm 10.2 \%$ to nonbiodegradable wastes. The organic material that could not be identified was classified as rapidly degraded waste. Further details regarding USW classification are given below.

\section{Physical and chemical analyses}

Table II summarizes the in-situ and ex-situ results of measured parameters. The temperature at half of the wells was below mesophilic conditions $\left(30^{\circ} \mathrm{C}\right)$, which could be due in part to exposure of the confined USW matrix to ambient air during sampling in combination, but also due to non-optimal confinement conditions as discussed below. Conversely, the $\mathrm{pH}$ was predominantly neutral, and an acidic $\mathrm{pH}$ of 6.1 was only observed at site 15 , whereas the most alkaline $\mathrm{pH}$ was 9.1. Moisture oscillated from 21.8 to $48.0 \%$, although the largest frequency was between 30 and $40 \%$, while the OF ranged from 
TABLE II. SUMMARY OF PHYSICAL AND CHEMICAL PARAMETERS OF MSW

\begin{tabular}{ccccccc}
\hline Quadrant & Well & OF $(\%)$ & Temperature $\left({ }^{\circ} \mathrm{C}\right)$ & $\mathrm{pH}$ & Moisture $(\%)$ & VS $(\%)$ \\
\hline \multirow{3}{*}{ I } & 3 & 36.0 & 26.5 & $9.1 \pm 0.1$ & $35.9 \pm 2.7$ & $66.3 \pm 2.0$ \\
& 8 & 37.1 & 41.8 & $8.7 \pm 0.0$ & $27.0 \pm 6.3$ & $82.4 \pm 1.7$ \\
& 13 & 75.9 & 40.4 & $9.1 \pm 0.0$ & $35.5 \pm 0.4$ & $82.9 \pm 0.8$ \\
& 14 & 41.0 & 35.5 & $8.8 \pm 0.2$ & $41.5 \pm 3.9$ & $79.7 \pm 0.8$ \\
& 15 & 38.3 & 34.3 & $6.1 \pm 0.2$ & $31.2 \pm 1.4$ & $78.9 \pm 1.5$ \\
\hline \multirow{2}{*}{ II } & 1 & 57.3 & 29.8 & $8.4 \pm 0.1$ & $31.4 \pm 7.5$ & $77.0 \pm 1.5$ \\
& 2 & 48.1 & 28.1 & $9.1 \pm 0.1$ & $38.7 \pm 2.7$ & $21.2 \pm 1.3$ \\
& 4 & 35.4 & 28.5 & $9.0 \pm 0.0$ & $48.0 \pm 5.0$ & $79.8 \pm 0.9$ \\
III & 16 & 61.0 & 27.5 & $7.1 \pm 0.1$ & $21.8 \pm 1.7$ & $84.7 \pm 1.1$ \\
\hline \multirow{4}{*}{ IV } & 5 & 79.8 & 27.2 & $8.3 \pm 0.1$ & $42.1 \pm 7.9$ & $82.4 \pm 0.6$ \\
& 6 & 77.4 & 24.4 & $8.3 \pm 0.3$ & $37.6 \pm 2.5$ & $74.8 \pm 2.8$ \\
& 7 & 55.6 & 33.4 & $8.2 \pm 0.10$ & $31.7 \pm 6.9$ & $77.5 \pm 0.5$ \\
\hline
\end{tabular}

35.4 to $79.9 \%$, which is a difference of more than $50 \%$. Interestingly, measurements of $\mathrm{OF}>50 \%$ were observed even in the oldest quadrants, presumably due to low biodegradation rates throughout the site. The results of the evaluated parameters suggest that the lack and use of reduced technology during construction, operation and closure of dump sites affect the biodegradation rates.

The observed moisture contents $(34.3 \%$ on average) were considerably lower than the optimal value of 65-70\% (Wall and Zeiss 1955, Reinhart et al. 2002). Additionally, the neutral $\mathrm{pH}$ and temperatures below the mesophilic range suggest that confinement conditions are not optimal for the development of microbial consortia. For instance, Angelidaki and Sanders (2004) found that a $\mathrm{pH}$ between 7 and 8 together with variations in the temperature of confined USW affect the biodegradation rates through the biodegradability of USW components. This could explain the observed OF biodegradation and the VS contents $>50 \%$ measured at all sampling sites except site 2. Interestingly, Hernández-Berriel et al. (2014) reported a decrease in VS of 22 to $27 \%$ during anaerobic degradation tests of confined USW in central Mexico in laboratory-scale bioreactors when moisture was maintained at $>50 \%$. In contrast, when moisture was not controlled and decreased beyond the optimal values, VS only decreased by $13 \%$. Moreover, González et al. 2011 previously observed a low correlation between biodegradation stages and USW confinement time in the Morelia dump.

\section{Lignocellulosic compounds}

It has been reported that little degradation of USW occurs during the first four years of confinement in landfills, while VS and CE start to decrease steadily thereafter (Kelly et al. 2006). In the current study, the measured OF was higher than that in developing countries. For instance, Chiemchaisri et al. (2007) investigated the USW characteristics at a pilot landfill cell in Thailand from 2001 to 2003 and observed a variation of OF between 4.1 and $54.6 \%$ when food and garden waste was considered to be dominant. To assess the biodegradation at the dumpsite, LI and CE + HE were measured in the collected samples. The levels ranged from 4.1 to $26.8 \%$ and from 29.5 to $53.3 \%$, respectively (Table III). The (CE + HE)/LI ratios oscillated between 1.6 and 12.3 , and appeared to be consistent with the values for fresh waste despite the relatively long confinement time. Similarly, the $\mathrm{LI}$ and CE + HE reported here are in good agreement with the results reported by Hernández-Berriel et al. (2014) of $20.3 \pm 0.3 \%$ and $61.7 \pm 0.4 \%$ in samples of fresh USW from an operating landfill. Interestingly, such landfill confines USW generated in Pátzcuaro, a city located $60 \mathrm{~km}$ south of Morelia that had a lower population of around 80000 inhabitants in 2010 .

The percentages of lignocellulosic compounds agree with those of $41-42 \%$ and $11-38 \%$ reported for $\mathrm{CE}$ and LI in developed countries (Hossain et al. 2003, Barlaz 2006), where wood wastes are predominantly cardboard and paper. This would also confirm that the development of non-optimal confinement 
TABLE III. SUMMARY OF LI AND CE + HE MEASURED IN THE COLLECTED SAMPLES AND ESTIMATION OF THE (CE + HE)/LI RATIOS

\begin{tabular}{lrrcc}
\hline Quadrant & Well & \multicolumn{1}{c}{ LI (\%) } & CE + HE $(\%)$ & $(\mathrm{CE}+\mathrm{HE}) / \mathrm{LI}$ \\
\hline & 3 & $9.5 \pm 0.8$ & $37.7 \pm 0.7$ & 4.0 \\
$\mathrm{I}$ & 8 & $4.2 \pm 0.7$ & $51.6 \pm 0.6$ & 12.3 \\
& 13 & $14.6 \pm 0.9$ & $48.8 \pm 0.9$ & 3.3 \\
& 14 & $20.5 \pm 0.8$ & $41.9 \pm 0.6$ & 2.0 \\
& 15 & $14.2 \pm 1.6$ & $38.1 \pm 1.5$ & 2.7 \\
\hline & 1 & $4.8 \pm 0.1$ & $51.6 \pm 1.2$ & 10.8 \\
II & 2 & $7.5 \pm 1.9$ & $53.3 \pm 0.7$ & 7.1 \\
& 4 & $19.8 \pm 1.6$ & $40.9 \pm 0.6$ & 2.1 \\
& 16 & $9.4 \pm 0.5$ & $50.3 \pm 0.5$ & 5.4 \\
\hline \multirow{4}{*}{ III } & 5 & $9.6 \pm 6.2$ & $29.5 \pm 0.9$ & 3.1 \\
& 6 & $8.4 \pm 0.6$ & $52.1 \pm 1.4$ & 6.2 \\
& 7 & $13.9 \pm 1.3$ & $46.0 \pm 0.3$ & 3.3 \\
\hline \multirow{2}{*}{ IV } & 9 & $23.1 \pm 3.3$ & $39.2 \pm 0.4$ & 1.7 \\
& 10 & $11.2 \pm 0.6$ & $43.5 \pm 1.2$ & 3.9 \\
& 11 & $19.3 \pm 1.3$ & $39.9 \pm 0.5$ & 2.1 \\
& 12 & $26.8 \pm 2.1$ & $44.2 \pm 0.7$ & 1.6 \\
\hline
\end{tabular}

CE: cellulose; HE: hemicellulose; LI: lignin

conditions at the study site affects the biodegradation rates, resulting in higher percentages of OF than at confinement sites operating and designed under official standards. Finally, the identified by-products suggest that, according to the MMB classification, the USW should be classified as rapidly degrading waste (Stege and Dávila 2009). However, the observed high percentages of LI and CE + HE suggest that USW could be classified as moderately slowly degraded wastes (González et al. 2011).

The VS test has traditionally been used to predict both biogas and $\mathrm{CH}_{4}$ production in USW (Kelly et al. 2006, González et al. 2011, Zheng et al. 2013). However, this test could lead to over-prediction of generation because of the presence of lowdegradation wastes (lignocellulosic compounds). Additionally, combining the VS with the LI and CE $+\mathrm{HE}$ assays enables more reliable estimations of $\mathrm{OF}$ biodegradability in USW. This is because the VS test does not provide information regarding the type of organic matter in the USW. Furthermore, the OF in Mexico contains high percentages of vegetable biomass, which is highly recalcitrant. Table III summarizes data obtained during LI and CE + HE measured in the collected samples, estimation of the $(\mathrm{CE}$ $+\mathrm{HE}) / \mathrm{LI}$ ratios. The results show low biodegradation despite the high contents of $\mathrm{OF}$, presumably due to the high percentages of lignocellulosic compounds in the USW as shown in Table II (Hernández-Berriel et al. 2014).

Table IV shows the Pearson correlation coefficients calculated for the relationships between the studied variables by quadrant. Overall, a large dispersion was found, with $\mathrm{R}^{2}$ ranging from 0.00 (LI vs. VS) to 0.99 (CE + HE vs. VS) in quadrant III Quadrants III and IV denote the close relationship between VS and moisture content, although this relationship was not significant $(p>0.05)$. Notably, the $(\mathrm{CE}+\mathrm{HE}) / \mathrm{LI}$ vs. VS correlation indicates that LI content plays a vital role for OF biodegradation. This is because high contents of CE and HE in the USW limit methanogenesis during the biodegradation processes, whereas high levels of LI block the microbial degradation of CE and HE (Barlaz et al. 1989).

The observed values of lignocellulosic compounds classify the waste as high OF with low biodegradation. Such information allows informed decisions to be made concerning the confinement of USW in developing countries. The results obtained in this study suggest that the installation of geomembrane cover materials could have two possible benefits: $i$ ) improving confinement conditions for OF biodegradation by maintaining high moisture contents and $i$ i) reducing seasonal variations in the matrix of confined USW caused by intense rainfall during summer. This was confirmed by Mendoza et al. (2013) and Hernandez-Berriel et al. (2014), who enhanced biodegradation rates by re-circulating leachates and concluded that the high content of LI interfered with the anaerobic biodegradation of CE.

TABLE IV. PEARSON CORRELATION COEFFICIENTS $\left(\mathrm{R}^{2}\right)$ CALCULATED FROM THE STUDIED VARIABLES

\begin{tabular}{lcccccc}
\hline Quadrant & LI vs. VS & $\begin{array}{c}\text { CE + HE + LI vs. } \\
\text { CE + HE }\end{array}$ & $\begin{array}{c}\text { Moisture vs. } \\
\text { VS }\end{array}$ & $\begin{array}{c}\text { CE + HE vs. } \\
\text { VS }\end{array}$ & $\begin{array}{c}\text { CE + HE + LI vs. } \\
\text { VS }\end{array}$ & $\begin{array}{c}\text { (CE + HE)/LI vs. } \\
\text { VS }\end{array}$ \\
\hline I & 0.02 & 0.33 & 0.06 & 0.51 & 0.62 & 0.06 \\
II & 0.09 & 0.13 & 0.08 & 0.26 & 0.14 & 0.04 \\
III & 0.00 & 0.94 & 0.33 & 0.99 & 0.89 & 0.66 \\
IV & 0.55 & 0.07 & 0.44 & 0.16 & 0.74 & 0.37 \\
\hline
\end{tabular}

CE: cellulose; HE: hemicellulose; LI: lignin; VS: volatile solids 


\section{CONCLUSIONS}

The composition of the confined USW in the studied site consisted of a heterogeneous mixture of $\mathrm{OF}$ at different stages of biodegradation. Evaluation of the VS, CE + HE and LI revealed that most of the OF has not been degraded. Categorization of the confined USW disagreed with the degradation index proposed in the MMB. This was ascribed to $i$ ) the presence of high contents of lignocellulosic compounds in the OF and $i$ ) the development of non-optimal confinement conditions that do not promote an efficient biodegradation. Therefore, it is important to include information concerning the biodegradability of $\mathrm{OF}$ to provide accurate estimations of the stabilization times of USW.

The current research corroborates the findings from other landfill sites in central Mexico, where low biodegradation rates of USW were observed because of high concentrations of lignocellulose. Previous studies and the results reported here have shown that the use of soil as cover material in Mexico and in other developing countries permits drastic changes in crucial parameters for biodegradation such as temperature and moisture in the matrix of confined USW. This severely limits the establishment of physicochemical conditions for optimal biodegradation of USW. Thus, it is suggested that geomembrane cover materials be installed in unregulated sites and that leachate recirculation be implemented to maintain moisture and improve biological conditions to enable higher biodegradation rates of OF than those reported here. Additionally, such systems could be combined with biogas capture systems to reduce the environmental impact of these facilities. Finally, these measures may reduce operating and post-closure management costs in confinement sites by decreasing the time required for OF stabilization.

\section{REFERENCES}

Alzate-Gaviria L.M., Pérez-Hernández A., Nevárez-Morillón V.G., Rinderknecht-Seijas N. and Poggi-Varaldo H.M. (2003). Comparison of two anaerobic coupled systems for biomethanation of organic fraction of urban solid wastes. Interciencia 28 (8), 436-442.

DOI: $10.1016 /$ j.ijhydene.2006.02.034

Angelidaki I. and Sanders W. (2004). Assessment of the anaerobic biodegradability of macropollutants. Rev. Environ. Sci. Biotech. 3 (2), 117-129.

DOI: $10.1007 / \mathrm{s} 11157-004-2502-3$
Ayse H. and Ferhan, S. (2003). Modeling of the anaerobic decomposition of solid wastes. Energ. Source. 25 (11), 1063-1072. DOI:10.1080/00908310390233586

APHA(2005). Standard methods for water and wastewater examination. 21st ed. American Public Health Association, Washington DC, $541 \mathrm{pp}$.

Barlaz M., Schaefer D. and Ham R. (1989). Bacterial population development and chemical characteristics of refuse decomposition in a simulated sanitary landfill. Appl. Environ. Microb. 55 (1), 55-65.

Barlaz M.A., Rooker A.P., Kjeldsen P., Gabr M.A. and Borden R.C. (2002). Critical Evaluation of factors required to terminate the postclosure monitoring period at solid waste landfills. Environ. Sci. Technol. 36, 3457-3464. DOI: $10.1021 / \mathrm{es} 011245 \mathrm{u}$

Barlaz M.A. (2004). Critical review of forest products decomposition in urban solid waste landfills. Technical bulletin No. 872. National Council for Air and Stream Improvement, Raleigh NC, 71 pp. [on line]. https:// www.ncasi.org/wp-content/uploads/2019/02/tb872. pdf 13/10/2017

Barlaz M.A. (2006). Forest products decomposition in urban solid waste landfills. Waste Manage. 26 (4), 321-333. DOI:10.1016/j.wasman.2005.11.002

Boni M. and Musmeci L. (1998). Organic fraction of urban solid waste (OFUSW): extent of biodegradation. Waste Manage Res. 16 (2), 103-107.

DOI: $10.1177 / 0734242 X 9801600202$

CESOP (2012). Residuos sólidos urbanos en México. Reporte CESOP 51. Centro de Estudios Sociales y de Opinión Pública, Cámara de Diputados, Mexico [on line]. www3.diputados.gob.mx/camara/content/ download/274147/851591/file/Reporte-51-Residusosolidos-urbanos-Mexico.pdf 13/10/2017

Chakraborty M., Sharma C., Pandey J. and Gupta P. (2011). Methane emission estimation from landfills in Delhi: A comparative assessment of different methodologies. Atmos. Environ. 45 (39), 7135-7142.

DOI: 10.1016/j.atmosenv.2011.09.015

Chandler J.A., Jewell W.J., Gossett J.M., van Soest P.J. and Robertson J.B. (1980). Predicting methane fermentation biodegradability. Biotechnol. Bioeng. Symp. 10. [on line]. https://www.osti.gov/scitech/biblio/6810537 $13 / 10 / 2017$

Chiemchaisri C., Chiemchaisri W., Kumar S. and Hettiaratchi J. (2007). Solid waste characteristics and their relationship to gas production in tropical landfill. Environ. Monit. Assess. 135, 41-48. DOI: $10.1007 / \mathrm{s} 10661-007-9706-2$

Colín-Urrieta S., García-Calderón M.A., López-Albarrán P. and Rutiaga-Quiñónez J.G. (2007). Análisis preliminar de la composición química de la madera de Cordia eleanoides DC. 4to. Congreso Forestal, IV 
Simposio Internacional sobre Técnicas Agroforestales, III Congreso International de Jóvenes Investigadores DEFORS 2007 y I Taller sobre Silvicultura Urbana Periurbana. Havana, April 17-20, 223 pp.

Crowe M., Nolan C., Collins C., Carty G., Donlon B. and Kristoffersen M. (2002). Biodegradable urban waste management - Part I: Strategies and instruments. European Topic Centre on Waste, European Environment Agency, Copenhagen [on line]. https://www.eea. europa.eu/publications/topic_report_2001_15_Part1/ download 19/08/2019

Dorairaja R. and Lifrieri J. (2010). Determination of landfill settlement of a urban solid waste of known composition based on $(\mathrm{C}+\mathrm{H}) / \mathrm{L}$ values. J. Solid Waste Technol. Manage. 36 (3), 66-76.

Eleazer W., Odle W., Wang Y. and Barlaz M. (1997). Biodegradability of urban solid waste components in laboratory-scale landfills. Environ. Sci. Technol. 31, 911-917. DOI: 10.1021/es9606788

Ezeah C., Fazakerley J. and Roberts C. (2013). Emerging trends in informal sector recycling in developing and transition countries. Waste Manage. 33 (11), 25092519. DOI: 10.1016/j.wasman.2013.06.020

González C., Buenrostro O., Márquez L., Hernández C., Moreno H. and Robles F. (2011). Effect of solid wastes composition and confinement time on methane production in a dump. J. Environ. Prot. 2, 1310-1316. DOI:10.4236/jep.2011.210151

Hernández-Berriel M., Mañón-Salas C., Buenrostro-Delgado O., Sánchez J. and Márquez L. (2014). Landfill leachate recirculation. Part I: Solid waste degradation and bio-gas production. Environ. Eng. Manage. J. 13 (10), 2687-2695. DOI: 10.30638/eemj.2014.299

INEGI (2010). Estadísticas ambientales y residuos. Instituto Nacional de Estadística y Geografía (INEGI) [on line]. http://mapserver.inegi.org.mx/ambiental/map/ indexV3FF.html 19/08/2019

Hossain M., Gabr M. and Barlaz M. (2003). Relationship of compressibility parameters to urban solid waste decomposition. J. Geotech. Geoenviron. 129, 1151-1158. DOI: 10.1061/(ASCE)1090-0241(2003)129\%3A12(1151)

Kayhanian M., Lindenauer K., Hardy S. and Tchobanoglous G. (1991). Two-stage process combines anaerobic and aerobic methods. BioCycle 32 (3).

Kelly R., Shearer B., Kim J., Goldsmith D., Hater G. and Novak J. (2006). Relationships between analytical methods utilized as tools in the evaluation of landfill waste stability. Waste Manage. 23, 419-423. DOI: 10.1016/j.wasman.2005.11.019

Komilis D. and Ham R. (2003). The effect of lignin and sugars to the aerobic decomposition of solid wastes. Waste Manage. 17 (1), 10-19.

DOI: $10.1016 / \mathrm{S} 0956-053 \mathrm{X}(03) 00062-\mathrm{X}$
Mehta R., Barlaz M., Asce M., Yazdani R., Augenstein D., Bryars M. and Sinderson L. (2002). Refuse decomposition in the presence and absence of leachate recirculation. J. Environ. Eng. 3, 228-236.

DOI: 10.1061/(ASCE)0733-9372(2002)128:3(228)

Meltzer R. (1979). Annual book of ASTM standards (wood and adhesives), vol. 22. ASTM International West Conshohocken, PA, EUA, 820 pp.

Mendoza E., Márquez L., Sánchez J., Buenrostro O. and Rutiaga J. (2013). Efectos de la recirculación de lixiviados sobre las propiedades físicas y químicas de los RSU sometidos a digestión anaeróbica. Rev. Int. Contam. Ambient. 29 (3), 73-78.

Pérez J., Muñoz J., de la Rubia T. and Martínez J. (2002). Bio-degradation and biological treatments of cellulose, hemicellulose and lignin: An overview. Int. Microbiol. 5, 53-63.

DOI: 10.1007/s10123-002-0062-3

Raposo F., de la Rubia M., Fernández V. and Borja B. (2011). Anaerobic digestion of solid organic substrates in batch mode: An overview relating to methane yields and experimental procedures. Renew. Sust. Energ. Rev. 16(1), 861-877. DOI: 10.1016/j.rser.2011.09.008

Reinhart D., McCreanor P. and Townsend T. (2002). The bioreactor landfill: its status and future. Waste Manage. Res. 20 (2), 172-186.

DOI: $10.1177 / 0734242 X 0202000209$

SEMARNAT (2013). Informe de la Situación del Medio Ambiente en México. Compendio de estadísticas ambientales. Indicadores clave y de desempeño ambiental. Edición 2012. Secretaría de Medio Ambiente y Recursos Naturales, México, 360 pp. [on line]. https:// apps1.semarnat.gob.mx:445/dgeia/informe_12/pdf/ Informe_2012.pdf 13/10/2017

SEMARNAT (2017). Normatividad aplicable al tema de residuos. Secretaría de Medio Ambiente y Recursos Naturales, México [on line]. https://www.gob.mx/ semarnat/acciones-y-programas/normatividad-aplicable-al-tema-de-residuos 13/10/2017

Srivastava V., Ismail S., Singh P. and Singh R. (2014). Urban solid waste management in the developing world with emphasis on India: challenges and opportunities. Rev. Environ. Sci. Biotechnol. 14 (2), 317-337. DOI: $10.1007 / \mathrm{s} 11157-014-9352-4$

Stege G. and Dávila J. (2009). User manual. Mexico landfill gas model v. 2.0 (Manual del usuario. Modelo mexicano de biogás v. 2.0). SCS Engineers, Phoenix AZ, EUA, 23 pp.

Thompson S., Sawyer J., Bonam R. and Valdivia J. (2009). Building a better methane generation model: Validating model with methane recovery rates from 35 Canadian landfills. Waste Manage. 29 (7), 2085-2091.

DOI: $10.1016 /$ j.wasman.2009.02.004 
Wall D. and Zeiss C. (1995). Urban landfill biodegradation and settlement. J. Environ. Eng. 121 (3), 214-224. DOI: 10.1061/(ASCE)0733-9372(1995)121:3(214)

Wise L., Murphy M. and Dádieco A. (1946). Chlorite holocellulose, its fractionation and beating on summative wood analysis and on studies on the hemicelluloses. Paper Trade 122, 35-45.

Yan W., Mahendrarajah P., Shaker A., Faisal K., Luong R and al-Ahmad R. (2014). Analysis of multi-temporal landsat satellite images for monitoring land surface temperature of urban solid waste disposal sites. Environ. Monit. Assess. 186 (12), 8161-8173. DOI: $10.1007 / \mathrm{s} 10661-014-3995-\mathrm{z}$

Zheng W., Phoungthong K., Lü F., Shao L. and He P. (2013). Evaluation of a classification method for biodegradable solid wastes using anaerobic degradation parameters. Waste Manage. 33 (12), 2632-2640.

DOI: 10.1016/j.wasman.2013.08.015 